\title{
倒立振り子モデルを利用した身体前後傾斜運動時の 立位安定性の定量評価に関する検討*
}

\author{
石田水里*1, 佐川貢 一*2 \\ Quantitative Evaluation for Standing Stability during \\ Anterior-Posterior Body Tilt Movement Using Inverted Pendulum Model
}

\author{
Mizuri ISHIDA and Koichi SAGAWA*3 \\ ${ }^{*}$ Course of Safety Science and Technology, Graduate School of Science and Technology, Hirosaki University, \\ 3 Bunkyo-cho, Hirosaki-shi, Aomori, 036-8561 Japan
}

\begin{abstract}
The purpose of this study is to obtain the quantitative indices of evaluation for standing stability during anterior-posterior tilt movement. We assumed human body in standing position which is modeled as a inverted pendulum, and two parameters based on control engineering, namely, natural frequency and damping ratio were estimated from the model for the quantitative indices. Twelve healthy volunteers participated in the experiment. Subjects inclined forward as large as possible around axis of the ankle joint mainly from upright standing, and recovered to the initial standing posture again. This task was executed in four conditions on the assumption that the standing stability decreased respectively as follows; both legs standing with eyes open, both legs standing with eyes closed, one leg standing using a tiltable step that prevents lateral sway, one leg standing without the step. The angular data at hip and ankle joint while the subject performed tilt movement followed by recovery were measured, and natural frequency and damping ratio were estimated using theoretical model about all conditions. The estimated parameters were compared anong four conditions. As the results natural frequency was more increased and damping ratio was more decreased according to the decrease of standing stability if the subject could execute the movement task by ankle joint mainly. On the other hand, when the larger movement at hip joint was measured, estimated indices suggested more unstable situation. It is comfirmed these two parameters are useful as the quantitative indices of evaluation for standing stability.
\end{abstract}

Key Words: Stability, Motion Control, Medical and Welfare Assistance, Analytical Model, Stand ing, Evaluation, Natural Frequency, Damping Ratio

\section{1. 緒 言}

リハビリテーション治療の一つである理学療法では, 立位安定性の低下を示す患者や高齢者を対象とする機 会が多い.このような被検者に立位安定性の向上を意 図した運動を指導したり，転倒などの危険性を防ぐた めには，立位姿勢制御能力を的確に評価し，把握でき なければならない，臨床的な評価の方法は多く存在す るが，“立位姿勢制御能力が高い”あるいは“立位安 定性が良好である”といった判定は㭘者の主観に依存 しやすく，定量的な評価指標は確立していない。 立位姿勢制御能力を評価する指標の一つとして，外 力 (床面が動く ${ }^{(1) \sim(5)}$ ，身体を押される $\left.{ }^{(6)(7)}\right)$ に対して

*原稿受付 2008 年 9 月 12 日。

*1 鳴海研究所清明会鳴海病院リハビリテーション部(画0368183 弘前市品川町 19), 弘前大学大学院理工学研究科 (画036-8561 弘前市文等町 3)

*2 正員, 弘前大学大学院理工学研究科安全システム工学專攻

E-mail : sagawa@cc.hirosaki-u.ac.jp
立位姿勢を保とうとするときの筋活動解析を利用す る方法が提案されている. しかし, 筋活動の解析は運 動戦略の把握に役立つ情報を与える一方で, 実際に 立位姿勢が安定しているかどうかを定量的に評価す る指標として十分とはいえない.ここで運動戦略に ついて簡単に説明する。運動戦略 (strategy) ${ }^{(2) \sim(4)} は$ 立位姿勢制御の応答を機能的に捉えるために重要な 考え方であり, 主要な立位姿勢制御の運動戦䊀には, ankle strategy, hip strategy, stepping strategy がある. ankle strategy は足関節を中心として, 重心 (center of gravity；以下，COG）が大きく逸脱しないよう制御す る運動戦略であり, 微細で素早い制御を可能にする. しかし, ankle strategy で制御できる運動範囲は限られ るため，より大きな $\mathrm{COG}$ の移動を強いられる状況で は，股関節を中心に身体を制御する hip strategy が有 利になる。さうに大きな $\mathrm{COG}$ 移動に対しては，足を 
踏み出す stepping strategy が用いられやすい.このよ うに, 運動戦略は立位安定性の程度を反映して機能的 に選択される.また，これらの運動戦略は単独で用い られるとは限らず, 複合的に現れる状況も多い。

立位安定性を定量的に評価するためには，姿勢・運 動をモデル化し，力学的パラメータを推定する制御工 学的な手法が役立つと考える. 左右方向の立位姿勢動 摇に着目した Kimura $ら^{(8)}$ の研究では，立位姿勢を多 リンク倒立振り子モデルへ適用して PID 制御のパラ メータ推定を試みている。ここでは，静的な立位姿勢 をビデオ撮影して左右方向の COG 移動量を求め, PID ゲインを推定した結果, 開眼の立位姿勢保持よりも閉 眼立位で微分ゲインが減少し，この傾向は加齢の影響 を受けてさらに顕著になることが見出された.これは， 立位安定性の変化を反映した指標となる可能性を示す 有用な知見である.しかし左右方向への可動性がほと んど生じない足関節の構造上，股関節主体の立位姿勢 制御となるため, ankle strategy も含めた運動戦略との 関連性を考慮して立位安定性を評価するのであれば左 右方向よりも前後方向の姿勢変化を利用する方が適す ると考える，前後方向の立位姿勢制御に関しては，足 関節の粘弹性を推定した報告 ${ }^{(9)}{ }^{(10)}$ が参考になるが, 足 関節のみを持つ単振り子モデルを適用させているため hip strategy の影響が考慮されていない.

そこで本研究では，立位安定性を評価するための定 量的な指標を得ることを目的として, 前後方向への立 位姿勢変化を解析し, 支持面を变化させない運動戦略 である ankle strategy と hip strategy を考慮した倒立振 り子モデル化によってパラメータを推定する．具体的 には，健常者を対象に立位安定性の変化を模擬した複 数の条件設定の下で身体前傾してから元の立位に戻 るときの足関節と股関節角度データを測定し，制御工 学的にシステムの安定性を表す変数として用いられて いる固有振動数と減衰比を推定した. 条件によるパラ メ一タ変化が見られるか比較することで，立位安定性 を反映した定量評価の指標としての利用可能性を検討 する.また, 求めたパラメータと運動戦略との関連性 についても考察する.

\section{2. 立位安定性評価パラメータ推定の原理}

立位安定性評価のパラメータ推定では，身体運動を 表現するためのリンクモデルを構築し，健常者を対象 とした身体前傾位から立位回復運動を施行した時の下 肢関節運動データをモデルに適用させる．立位姿勢は， 図 1 に示すような 2 リンクおよび 1 リンクの倒立振り 子モデルで表現する.ここで, 2 リンクモデルは足関

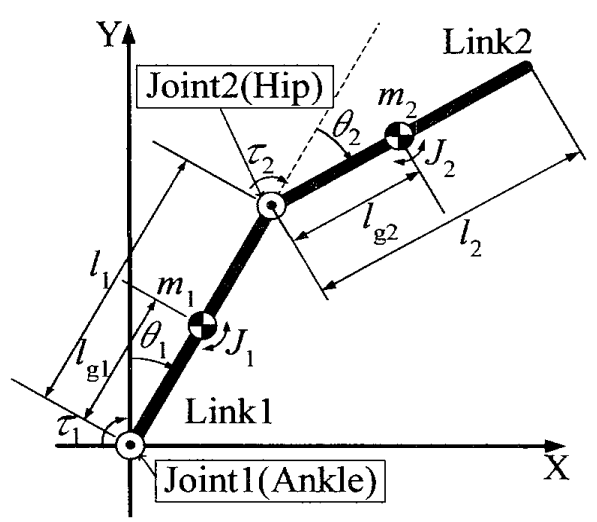

(a)

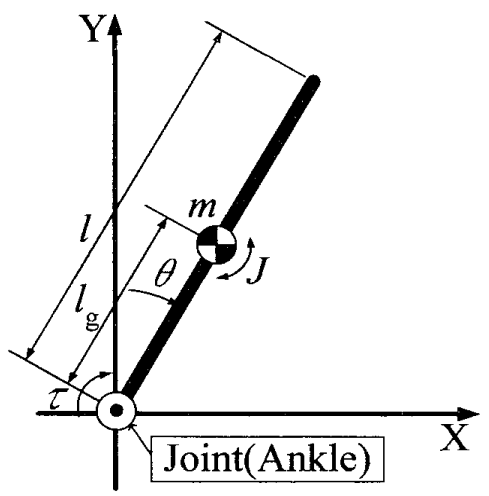

(b)

Fig. 1 Link models for standing posture (a) Two link model, (b) One link model

節と股関節を持ち，2 リンクモデルのリンク 1 は足関 節から股関節までの下肢, リンク 2 は股関節以上の部 分で頭部と体幹から構成される. $\theta_{1}$ はY 軸からの足関 節角度, $\theta_{2}$ はリンク 1 からリンク 2 までの股関節角度 を表し, $m_{i}$ は各リンク質量, $l_{i}$ はリンク長, $l_{g i}$ は関節 から質量中心までの長さ， $J_{i}$ は各リンク質量中心まわ りの慣性モーメント， $\tau_{i}$ は関節まわりのトルクである （すべて $i=1,2 ）$. 各関節トルク $\tau_{1}, \tau_{2}$ は PD 制御に よって立位を調節する機構と仮定し, 比例ゲイン $K_{P 1}$, $K_{P 2}$, 微分ゲイン $K_{D 1}, K_{D 2}$ に応じて変化する. 同様に 1 リンクモデルでは, $\theta$ は Y 軸からの足関節角度, $m$ はリンク質量, は はリンク長, $l_{g}$ は足関節から質量中 心までの長さ, $J$ は質量中心まわりの慣性モーメント, $\tau$ は足関節まわりのトルクで $K_{P 1}$ と $K_{D 1}$ によって調節 される.2つのモデルを用いる理由は以下の通りであ る. 運動は足関節を中心に行うため ankle strategy が主 に作用するが，不安定な条件になると hip strategy の 関与が大きくなる可能性も考えられる. 本研究と同様 に足関節を主体とした身体前傾・回復運動を行うよう 被検者に指示して得られた関節運動データ及び床反力 
データを基に，1 リンクモデルを適用して足関節トル クの状態を推定したStephen ら ${ }^{(11)}$ は, 実験時に被検者 によっては大きな股関節運動も観察され立位姿勢制御 に対する hip strategy の関与は否定できないと述べて いる. そこで，本研究ではまず足関節と股関節運動を 考慮した 2リンクモデルから各関節の比例ゲインと微 分ゲインを推定した後で, 足関節に関する比例ゲイン, 微分ゲインから 1 リンクモデルとして簡略化し，さら に無次元化した固有振動数 $\omega$ と減衰比 $\zeta$ を求めて立 位条件間の比較に用いるという 2 段階の手順をとる。 最終的に 1 リンクモデルへ簡略化したのは， $\omega$ ととの 2 パラメータが立位安定性を表現する代表的な指標で あると見なすことができれば，臨床評価へ応用する際 に理解しやすく実用性も高まると考えたからである. 足関節と股関節を持つ 2 リンクモデルの関節トルク $\tau_{1}, \tau_{2}$ は,

$$
\tau_{i}=K_{P i}\left(\theta_{d i}-\theta_{i}\right)+K_{D i}\left(\dot{\theta}_{d i}-\dot{\theta}_{i}\right) \quad(i=1,2)
$$

と表される. $\theta_{d i}$ は各関節の目標角度, $\dot{\theta}_{d i}$ は目標角速 度である. Lagrange法によりモデルの運動方程式を導 出すると

$$
\begin{aligned}
& {\left[m_{1} l_{g 1}{ }^{2}+J_{1}+m_{2}\left(l_{1}^{2}+2 l_{1} l_{g 2} \cos \theta_{2}+l_{g 2}{ }^{2}\right)+J_{2}\right] \ddot{\theta}_{1} } \\
& +\left[m_{2}\left(l_{1} l_{g 2} \cos \theta_{2}+l_{g 2}{ }^{2}\right)+J_{2}\right] \ddot{\theta}_{2} \\
& -m_{2} l_{1} l_{g 2}\left(2 \dot{\theta}_{1} \dot{\theta}_{2}+\dot{\theta}_{2}^{2}\right) \sin \theta_{2} \\
& -m_{1} \hat{g} l_{g 1} \sin \theta_{1}-m_{2} \hat{g}\left[l_{1} \sin \theta_{1}+l_{g 2} \sin \left(\theta_{1}+\theta_{2}\right)\right] \\
= & K_{P 1}\left(\theta_{d 1}-\theta_{1}\right)+K_{D 1}\left(\dot{\theta}_{d 1}-\dot{\theta}_{1}\right) \\
& {\left[m_{2}\left(l_{1} l_{g 2} \cos \theta_{2}+l_{g 2}{ }^{2}+J_{2}\right)\right] \ddot{\theta}_{1}+\left(m_{2} l_{g 2}{ }^{2}+J_{2}\right) \ddot{\theta}_{2} } \\
& +m_{2} l_{1} l_{g 2} \dot{\theta}_{1}^{2} \sin \theta_{2}-m_{2} \hat{g} l_{g 2} \sin \left(\theta_{1}+\theta_{2}\right) \\
= & K_{P 2}\left(\theta_{d 2}-\theta_{2}\right)+K_{D 2}\left(\dot{\theta}_{d 2}-\dot{\theta}_{2}\right)
\end{aligned}
$$

となり，最小自乗法を用いて $K_{P 1}, K_{P 2}, K_{D 1}, K_{D 2}$ を 得る. $\hat{g}$ は重力加速度である.

推定した比例ゲインと微分ゲインのうち足関節に関 する $K_{P 1}$ と $K_{D 1}$ を 1 リンクモデルに適用して $\omega, \zeta を$ 求める. 1 リンクモデルの運動方程式は, 足関節角度 $\sin \theta \approx \theta$ と近似して

$$
\left(m l_{g}^{2}+J\right) \ddot{\theta}-m \hat{g} l_{g} \theta=K_{P 1}\left(\theta_{d}-\theta\right)+K_{D 1}\left(\dot{\theta}_{d}-\dot{\theta}\right)
$$

と表す. さらに $\theta_{d}$ を入力, $\theta$ を出力とする伝達関数 $G(s)$ は

$$
G(s)=\frac{\Theta}{\Theta_{d}}=\frac{1}{m l_{g}^{2}+J} \cdot \frac{K_{D 1} \cdot s+K_{P 1}}{s^{2}+2 \zeta \omega s+\omega^{2}}
$$
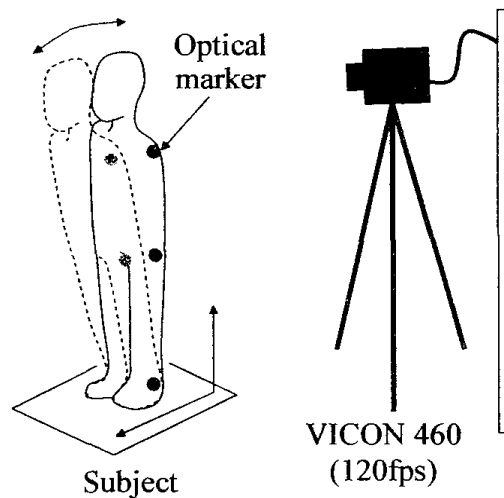

Fig. 2 Experimental setup

と表される.ただし，

$$
\begin{gathered}
\omega=\sqrt{\frac{K_{P 1}-m \hat{g} l_{g}}{m l_{g}^{2}+J}} \\
\zeta=\frac{K_{D 1}}{2 \sqrt{\left(m l_{g}^{2}+J\right)\left(K_{P 1}-m \hat{g} l_{g}\right)}}
\end{gathered}
$$

である. 特性方程式

$$
s^{2}+2 \zeta \omega s+\omega^{2}=0
$$

の根 $s$ は,

$$
s=-\zeta \omega \pm \omega \sqrt{\zeta^{2}-1}
$$

となり, 制御工学に扔るシステムの安定条件として ら>0であることが要される.

\section{3. 立位安定性の異なる条件での前後傾斜運動実験}

3.1 実験方法 実験方法の概略を図 2 に示す. 被 検者は健常成人 12 名（男性 7 名, 女性 5 名）を対象 とした，被検者の平均年齢は $22.4 \pm 1.2$ 歳，平均身長 は $166.9 \pm 7.3[\mathrm{~cm}]$, 平均体重は $58.6 \pm 6.2[\mathrm{~kg}]$ であっ た. 実験に先立ち, 被検者には研究の目的と実施方法 を説明し，同意を得た。

被検者には直立姿勢から自力でできるだけ大きく前 傾運動を行い，再び最初の直立姿勢に戻る課題を施行 してもらう.この際, 股関節の運動はなるべく伴わず 足関節を中心に運動することをあらかじめ指示してお いた.

課題は，運動時の立位安定性が異なることを想定し た以下の 4 つの条件の下で施行した.

1. 両脚 - 開眼 (Eyes-open ; 以下, EO)

開眼で両脚接地した立位をとり, 前傾・回復運 動を行う. 
2. 両脚・閉眼 (Eyes-closed；以下，EC）

閉眼で両脚接地した立位をとり, 前傾・回復運 動を行う.

3. 片脚・台あり (One leg with step ; 以下, OLS)

開眼で片脚立位をとり，前傾・回復運動を行 う. 挙上側の下肢はシーソーのように角度が自 由に変化する補助台上に支持した状態で運動する (図 3(a)).

4. 片脚・台なし（One leg without step；以下, OL） 開眼で片㑢立位をとり，前傾・回復運動を行う. 挙上側下肢に対し補助台は使用せず，空間上に自 力で保持した状態で運動する（図 3(b)）.

これらの条件は $\mathrm{EO} \rightarrow \mathrm{EC} \rightarrow \mathrm{OLS} \rightarrow \mathrm{OL}$ の順に立位安 定性が低下することを模擬した設定である。なお， OLS，OL の片脚立位は左下肢を支持側，右下肢を挙 上側とした.これらの 4 条件につき，5回ずつ前傾運 動・回復課題を繰り返した，測定条件配置は，順序の 効果を相殺するため循環法を利用した.

股関節および足関節角度は，図 2 のように被検者 の左側肩峰, 大転子, 外果に反射マ一力を貼り付け, 上肢を組んだ立位姿勢から各条件に従って運動を行っ てもらい，運動時の立位姿勢を VICON 460 (VICON MOTION SYSTEMS）で撮影して求めた（サンプリン グ周波数 $120[\mathrm{~Hz}]$ ）。VICON 460 では 6 台のカメラを 使用し, 各マ一力の 3 次元位置が記録される. 本研究 では, 矢状面方向の運動に関する 2 次元位置のみを データとした．記録したマーカの座標から，股関節角 度と足関節角度を求めた. さらに角度を数值微分して 角速度と角加速度を得た ${ }^{(12)}$. すべての関節運動データ （角度, 角速度, 角加速度）は, 足関節背屈を正方向, 底屈を負方向の運動，股関節屈曲を正方向，伸展を負 方向の運動として定義する.

3.2 リンクパラメータの算出 リンク長や慣性

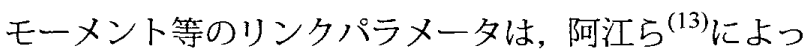
て報告されている身体部分慣性係数を利用する．これ らの係数は日本人青年アスリートを対象として男女別 に得られているが，日本の若年成人男女の定数として 力学的解析に利用可能とされている ${ }^{(14) \sim(16)}$. 本研究で は，被検者の身体を頭部，体幹，上腕，前腕，手，大 腿, 下腿, 足部の各部分に分けて部分長を計測し, 部 分長と体重をもとに身体部分慣性係数を適用して 2リ ンクないし1 リンクモデルに相当するリンクの質量と 質量中心位置, 慣性モーメントを算出した.

$3 \cdot 3$ 立位安定性評価パラメータの推定＼cjkstart関節運 動データとリンクパラメータを2リンクモデルの運動 方程式(2)，(3)に代入し，最小自乗法によって各リン

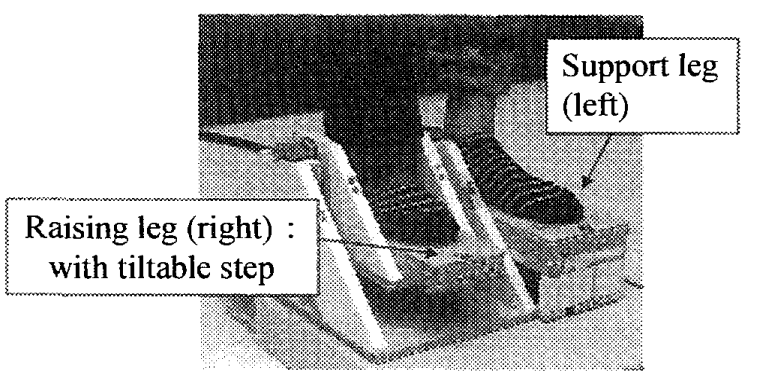

(a)

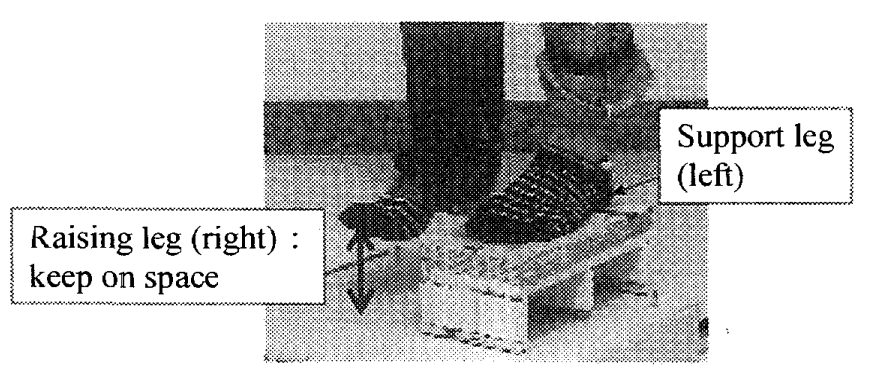

(b)

Fig. 3 Condition of movement at one leg (a) One leg with step (OLS), (b) One leg without step (OL)
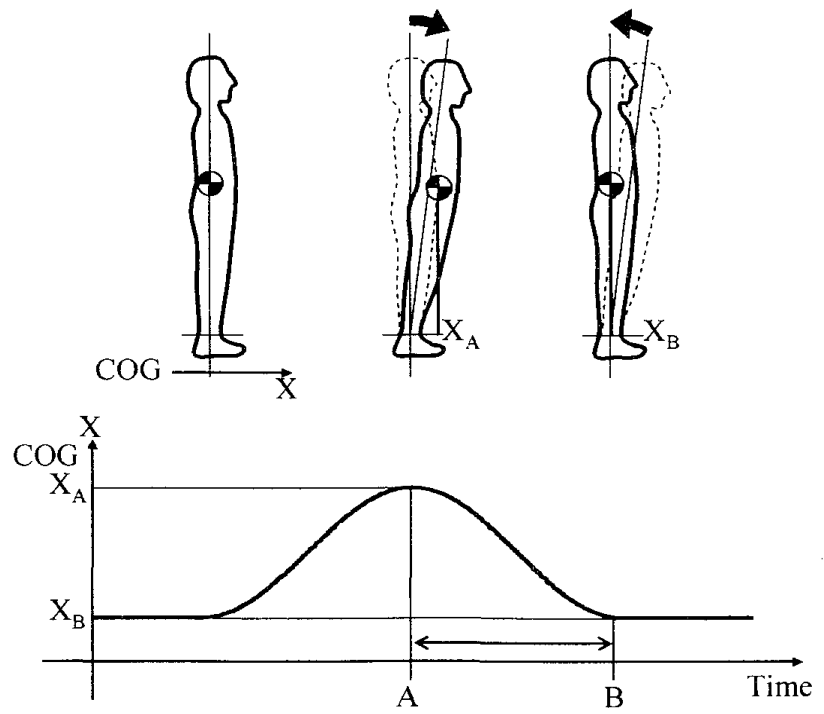

Fig. 4 Time range used to estimate model parameters

クごとに比例ゲイン，微分ゲインを推定する. 最終的 に，1リンクモデルに適用させた式(6), 式(7)から $\omega$ とらを得る.

身体を前傾していく区間と立位姿勢を回復する区間 とでは，立位姿勢制御の制御則が異なると予測される ため, パラメータの推定はこれらの区間ごとに分けて 行う必要があると考える.これら 2 つ間のうち, 前傾位から立位姿勢を回復する区間では各関節の目標 角度扔よび目標角速度の值を 0 と仮定できることか ら, 本研究では立位姿勢を回復する区間に限定してパ 


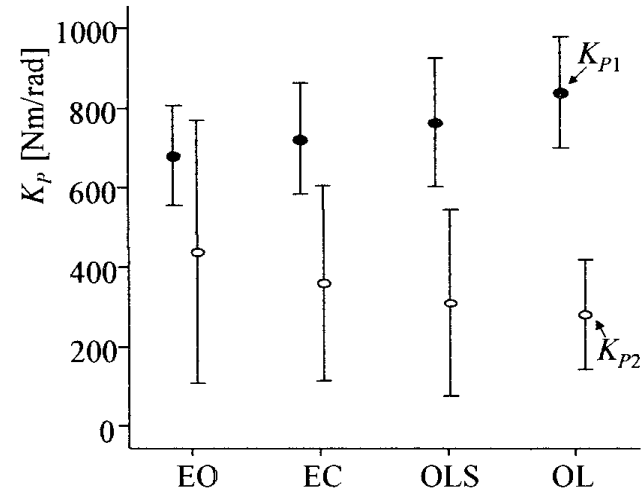

Fig. 5 Calculated $K_{P}$ in four conditions

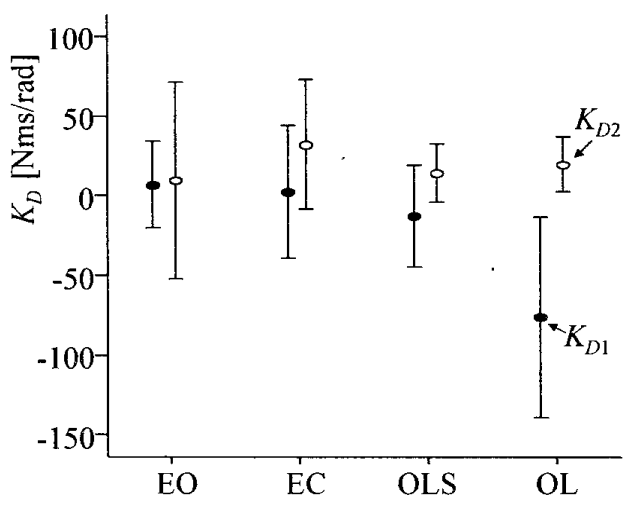

Fig. 6 Calculated $K_{D}$ in four conditions

ラメータ推定を行った。この判断には, $\mathrm{COG}$ の前方 移動量を利用する。 COG 位置は関節角度とリンクパ ラメータから求め, 前方移動量の最大值から最小值ま での範囲をパラメータ推定区間とした。図 4 のA 点 は $\mathrm{COG}$ 前方移動量が最大値 $X_{A}$ となる時刻, $\mathrm{B}$ 点は 立位回復後に最小值 $X_{B}$ となる時刻であり，パラメー タ推定区間は $\mathrm{A}$ 点から B 点までの区間とした。なお, 各関節角度, 角速度, 角加速度は $\mathrm{COG}$ 前方移動が最 小值となる時刻（パラメータ推定区間の終端 $\mathrm{B}$ 点）で の值が 0 となるように測定データのオフセットを調整 し, 各試行ごとの比例ゲインと微分ゲイン， $\omega, \zeta を$ 求めた.

3.4 データ解析 $\omega$ ととについて各被検者の条 件別に 5 回測定の平均值を求め, 多重比較法を適用し て立位の条件による違いがあるか解析した。有意水準 は $5 \%$ とし，有意水準以下の值を有意差ありとした。

\section{4. 結果}

推定した比例ゲイン $K_{P 1}, K_{P 2}$ の值を図 5 に, 微分ゲイン $K_{D 1}, K_{D 2}$ の值を図 6 に示した。 $\mathrm{EO} \rightarrow \mathrm{EC} \rightarrow \mathrm{OLS} \rightarrow \mathrm{OL}$ の順に，つまり不安定とな りやすい立位条件になるに従い足関節の比例ゲイン

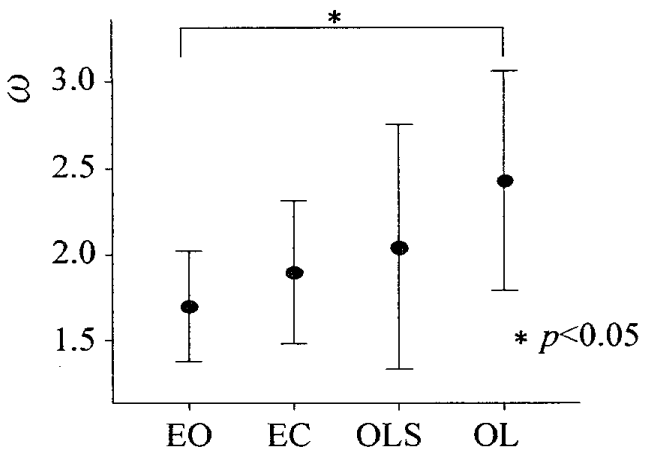

Fig. 7 Estimated $\omega$ in four conditions

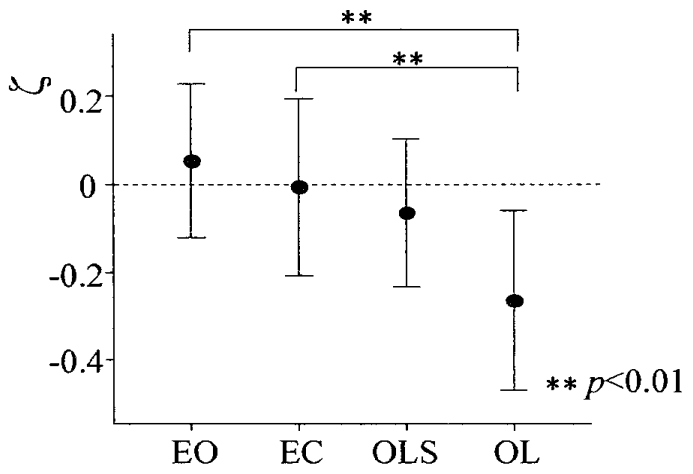

Fig. 8 Estimated $\zeta$ in four conditions

$K_{P 1}$ は大きく, また, 股関節の比例ゲイン $K_{P 2}$ は小 さくなる傾向があった. 同順に足関節の微分ゲイン $K_{D 1}$ は小さくなる傾向にあったが, 股関節の微分ゲ イン $K_{D 2}$ は条件の違いによる明確な変化は見られな かった。

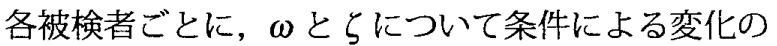
パターンを観察したところ, $\mathrm{EO} \rightarrow \mathrm{EC} \rightarrow \mathrm{OLS} \rightarrow \mathrm{OL}$ の順 に $\omega$ が大きくなるパターンを示した者は 7 名 (58.3\%) でまた同順にらが小さくなるパターンを示した者も 7 名 (58.3\%) 存在していた. 図 7 には $\omega$ の多重比較 による検定結果を示した， $\omega$ の值は不安定な立位条件 ほど大きくなる傾向があり，OL では EO よりも有意 に大きかった $(p<0.05)$. らの検定結果は図 8 に示 した. 不安定な条件になるに従いらは小さくなる傾向 があり，OL は EO および EC の条件よりも有意に小 さくなる結果となった（いずれも $p<0.01 ）$. 平均值 を見ると，EOの条件以外は 0 以下の小さい值となっ ており, 制御工学的に不安定となっていることがわか

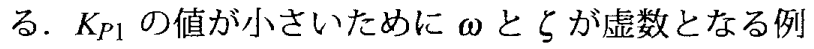
が OL で 1 回存在し, 解析からは除外した.

測定されたすべての関節運動を観察すると, 股関節 角度は様々な大きさで変化していた，図 9 は EO の条 件で観察された異なる被検者の関節角度例である。と 

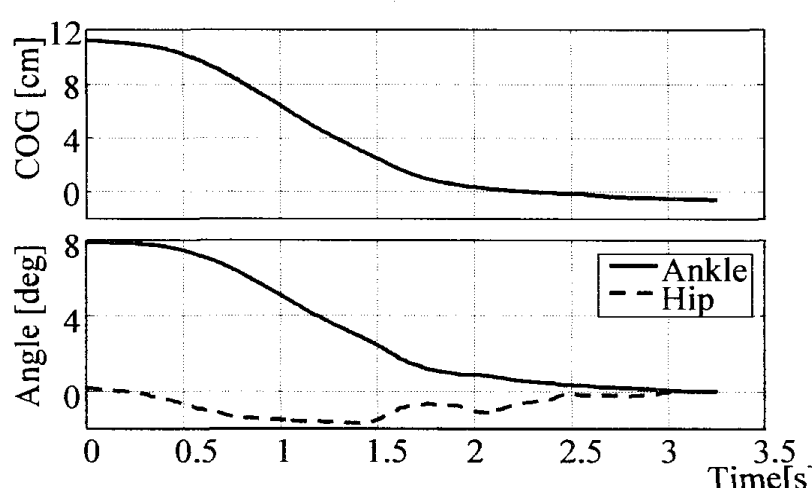

(a)
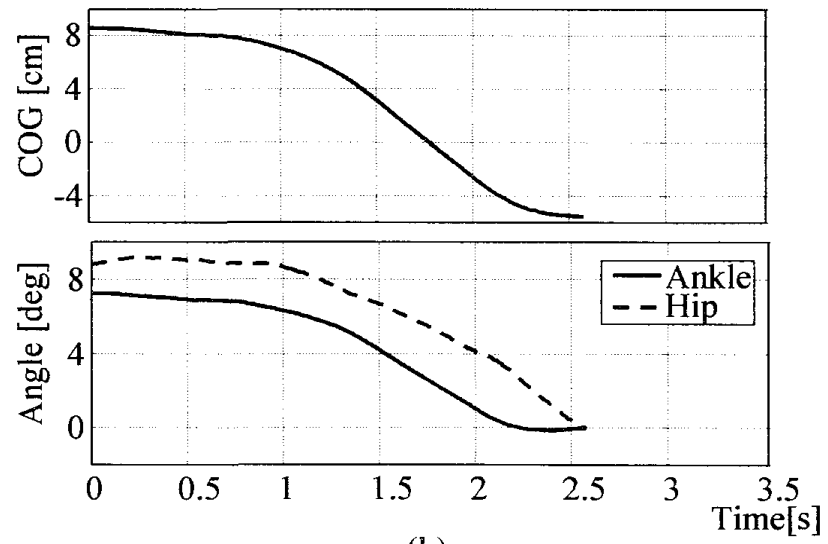

(b)

Fig. 9 Examples of $\mathrm{COG}$ and joint angle in $\mathrm{EO}$ condition (a) A case that ankle angle is larger than hip one, (b) A case that hip angle is larger than ankle one

もに足関節背屈角度の最大值は $8[\mathrm{deg}]$ 程度であるが, (a)の例では股関節角度の変化が小さく主に足関節背 屈で前傾・回復運動を施行できている。一方, (b) の 例では股関節屈曲角度が足関節背屈角度よりも大き い. そこで各運動試行ごとに足関節背屈角度と股関節 屈曲角度の最大值を比較し, 足関節角度が大きい場合 $\left(\theta_{1}>\theta_{2}\right)$ と股関節角度が大きい場合 $\left(\theta_{1}<\theta_{2}\right)$ とに

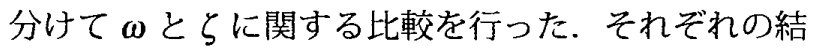
果は図 10 , 図 11 に示す. $\omega$ は足関節角度が大きい場 合も股関節角度が大きい場合も，大まかに見ると EO よりも他の条件で值が大きくなる傾向はあるものの, 図 7 ほどの明確な傾向とはいえず, 統計的な有意差も 認められなかった. らについては，足関節角度が大き い場合には，不安定な立位条件となるに従い値が小さ くなる傾向は変わらず, OL では EOよりも有意に小 さかった $(p<0.05)$. 股関節角度が大きい場合には, らの傾向は異なっていた.すべての条件で，足関節角 度が大きい場合よりも股関節角度が大きい場合で $\omega$ が 大きくなるとともに，らが小さくなる特徴があった.

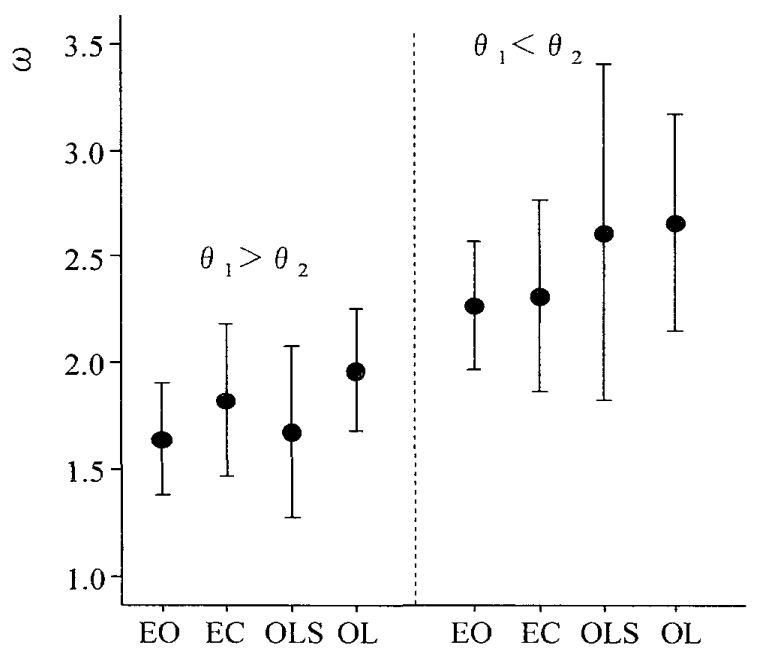

Fig. 10 Result of estimated $\omega$ in four conditions according to the difference between ankle angle $\theta_{1}$ and hip one $\theta_{2}$

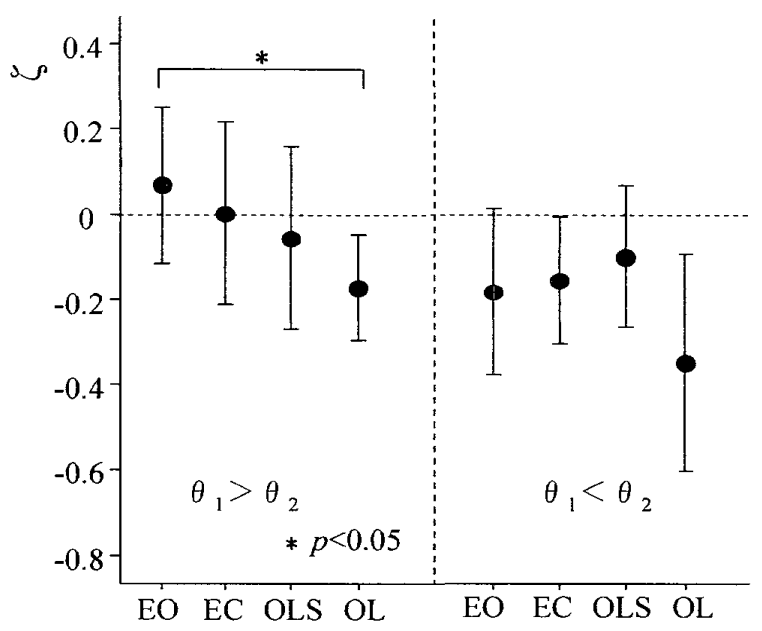

Fig. 11 Result of estimated $\zeta$ in four conditions according to the difference between ankle angle $\theta_{1}$ and hip one $\theta_{2}$

その他の関節運動の特徴として, 足関節・股関節角 度は立位に戻るに従い減少していくのに対し, 角速度 は徐々に減速しているとは限らず, 全体的に值の変動 が顕著である例や，データの前半 (最大傾斜) では大 きくないが後半（直立姿勢に戻る直前）で值の変動が 大きく不安定になっている例などが観察された．実際 に実験中に観察された立位姿勢でも，明らかにふらつ きがあり不安定で股関節運動によってかろうじて直立 姿勢に戻っていたり，特に OL では立位に戻る前に下 肢を踏み出してしまった場合が存在していた．前者の ような立位姿勢の不安定例はデータに採用しているが, 
後者のように明らかに課題を遂行できなかった例は測 定をやり直しておりデータには含まれていない.

\section{5. 考察}

被検者に対してはできる限り股関節の運動を伴わな ずに身体前傾・回復するよう指示を与えており，ankle strategy を用いた立位姿勢制御が望ましい運動課題で ある. ankle strategy は効率に優れ素早い応答を可能に する運動戦略である分，微細な制御能力を要される. 対して hip strategy は効率では劣るが安全性に優れ, 微 細な制御能力が要求されないため患者や高齢者のよう に立位姿勢制御能力の低下が見られる者では, ankle strategy よりも hip strategy が優位に出現しやすい特徵 がある ${ }^{(17)}$. 健常者にとっては ankle strategy で応答で きる安定した状況であっても，立位姿勢制御能力が低 下していると hip strategy で答せざるを得ないとい う現象は臨床上よく観察される. 今回の実験において, 健常者でも ankle strategy 主体に課題を遂行できた例 と hip strategy が優位に用いられた例とが存在する状 況であった． $\omega$ は式 (6)より，0であれば静止立位を 保持するために最低限必要となる足関節トルクを発揮 している状態ということになる，従って， $\omega$ が小さい と ankle strategy によって効率よく制御できる状態と 考える．逆に $\omega$ が大きくなると，足関節の剛性を高 めて転倒しないようあらかじめ防御するような制御が 必要となり，さらに ankle strategy のみで対応する余裕 がないために hip strategy に依存しやすい状態を表し

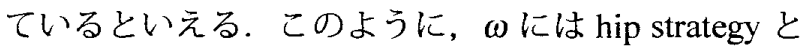
対比して ankle strategy を捉えた場合の“運動戦略の 優位性”が反映されたと考えた。

らは不安定となりやすい条件ほど小さくなり，負の 值になることも多かった，本手法では，最大傾斜姿勢 から直立姿勢に戻るまでの広いデー夕範囲を用い，最 小自乗法で推定した結果であるため, データの特徵 的な部分に影響を受けやすい性質がある．実際の立位 姿勢および関節角速度の観察上，最終的に静止立位に なってはいるものの運動中は明らかに不安定と判断で きる部分が存在したことから，局所的に不安定な動作 が多ければ負の值としてらに反映された可能性があ る. くは円滑で安定した運動が行われている，あるい は振動的で不安定な運動が行われているといった“関 節運動の制御特性”を表していると解釈した。

臨床的に立位安定性を判断する上で，運動戦略の状 況と関節運動の特性は両者とも重要な要素である，先 に述べたように，ankle strategy よりも hip strategy の 優位となる状態は安定性の低下を示唆する。一方で,

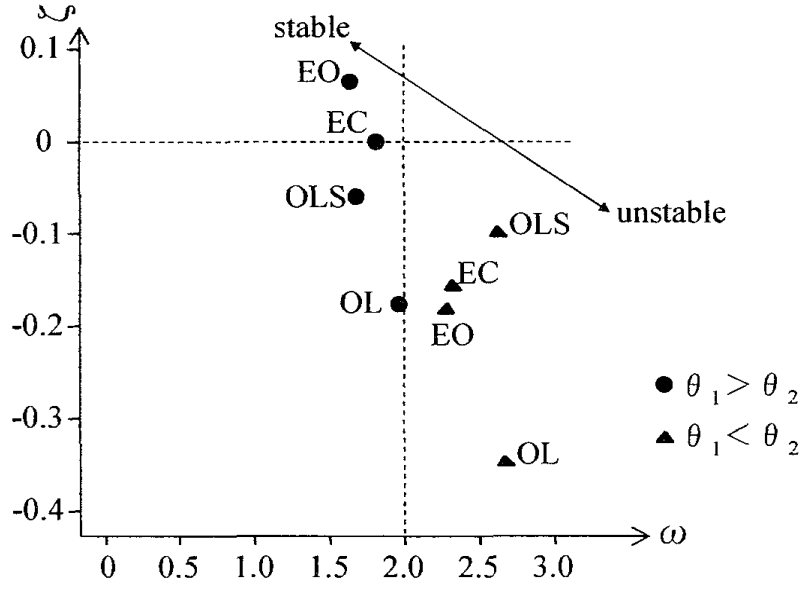

Fig. 12 Relation between estimated $\omega$ and $\zeta$ in four conditions

仮に ankle strategy が優位であっても，立位姿勢のふ らつきが大きければ安定性が高いとは判断し難い。こ れらのことから， $\omega$ とらの数值を個々に見るだけでな く，両方の特性を総合的に知ると立位安定性の判断に 役立つと考える. 図 12 は，各条件ごとの $\omega$ の平均值 を横軸，〈の平均值を縦軸とする関係性を表すグラフ で，足関節角度が大きい場合と股関節角度が大きい場

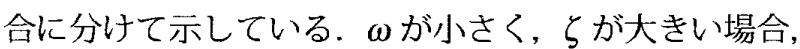
つまりグラフの左上ほど ankle strategy が優位かつ立 位姿勢のふらつきが小さい“安定な状態”，逆に $\omega$ が

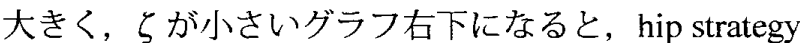
が優位かつ立位姿勢のふらつきが大きい“不安定な状 態”と理解できる．すなわち，足関節角度が大きい場 合のEO で最も安定し，股関節角度が大きい場合の OL が最も不安定といえる．数值的には， $\omega$ は 2 付近を境

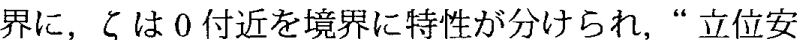
定性”を判断する一つの基準として利用できる可能性 がある. 無次元化された変数である $\omega$ とらを求めて いるため，身体特性には依存せず，被検者間で数值を 比較して用いることもできるであるう。

本研究では股関節運動が生じることをあらかじめ 考慮し，2 リンクモデル適用後に簡略化した 1 リンク モデルへ適用し $\omega$ とらを推定する手法を行っている. 参考までに，股関節運動の測定值は使用せずに初めか ら 1 リンクモデルのみを適用させて $\omega$, $\zeta$ を求めた. 図 13 は，本手法と対比させた結果である.1リンク モデルのみを適用させた結果では，2 リンクモデルを

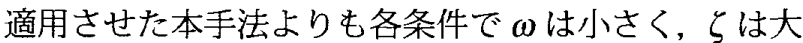
きい傾向にあった．多重比較法で確認すると， $\omega, \zeta$ とも 1 リンクモデルのみを適用させた場合は立位条件 

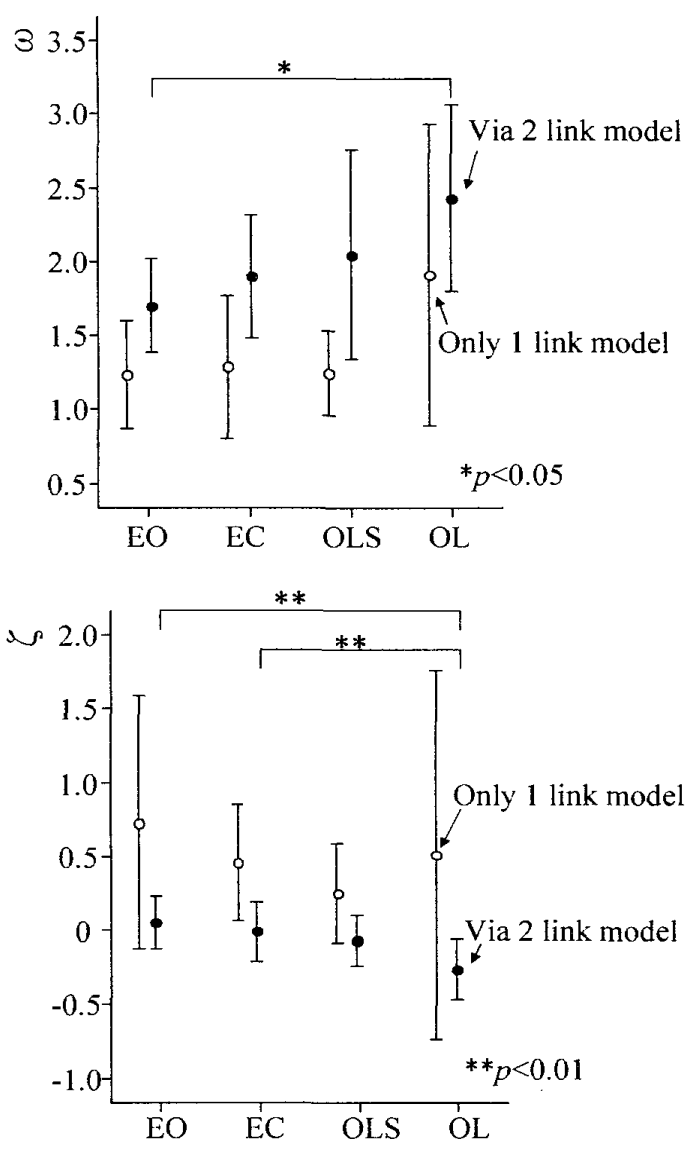

Fig. 13 Contrast with $\omega$ and $\zeta$ values estimated by only one link model

による違いは認められず，立位安定性の変化を鋭敏に 把握するためには股関節運動の考慮が重要であること が示された。 また， $K_{P 1}$ の值により $\omega$ と $\zeta$ が虚数と なった例は 6 回存在し, 足関節運動だけを考慮した 1 リンクモデルは不十分であると考える. パラメータ推 定の妥当性について今後さらに詳しく検討する余地は あるが，股関節運動を考慮した本手法は， hip strategy が優位となる患者や高齢者に対しても適用できる可能 性を示し，臨床的意義は大きい。

臨床応用における汎用性という点では, 設定や実験 に要する時間が短く, 使用機器, 設備が安価で簡便で あることが重要となるが, 今回使用した光学式動作解 析装置は高額であり，どこでも利用できるとは限らず， また機器の設定にも時間を要する. そこで, 安価で入 手しやすく機器の設定も容易な加速度センサとジャイ 口を利用した角度計測手法を現在検討している。佐川 ら ${ }^{(18)}$ の報告によると, ジャイロで計測された角速度 データの積分精度は高く, ビデオ画像による動作解析 結果と比較した誤差は非常に小さいことが証明されて
おり，今回提案した手法にも同様に適用可能である. 実験の手順自体は短時間で簡便に施行できるため, 使 用機器の課題を解決することで高い汎用性を期待で きる.

\section{6. 結論}

立位安定性を定量的に評価するための指標を得るこ とを目的として, 安定性变化を模擬した条件下で身体 前傾・回復運動を行ったときの足関節・股関節運動を 解析し, 倒立振り子モデルへの適用により力学的パラ

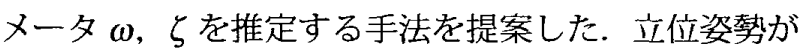
不安定となりやすい条件になるに従い， $\omega$ は大きく

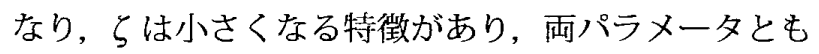
立位条件による有意な違いも認められた．さらに，身 体前傾・回復の運動課題を足関節運動主体に行う例と 股関節運動が大きくなる例とが観察され, 值の傾向は 各々で異なることがわかった．結果を総合的に見ると， $\omega$ には足関節と股関節による “運動戦略の優位性”を 表し，らには立位姿勢のふらつきなどといった不安定 性に関わる“関節運動の制御特性”を表していると解 釈できた. 従って， $\omega と \zeta の$ 両特性を把握することで, 理学療法の臨床におりる立位安定性評洒へ応用できる 可能性が示されたといえる.

\section{文献}

(1) Nashner,L.M., Fixed Patterens of Rapid Postural Responces among Leg Muscles during Stance, Experimental Brain Research, Vol.30 (1977), pp. 13-24

(2) Nashner,L.M., Adaptation of human movement to altered environments, Trends in Neurosciences, Vol.5 (1982), pp.358-361

(3) Nashner,L.M.,Black,F.O.,Wall,C.III, ADAPTATION TO ALTERED SUPPORT AND VISUAL CONDITIONS DURING STANCE: PATIENTS WITH VESTIBULAR DEFICITS, The Journal of Neuroscience, Vol.2,No.5 (1982), pp.536-544

(4) Horak,F.B.,Nashner,L.M., Central programming of postural movements: adaptation to altered support surface configurations, Journal of Neurophysiology, Vol.5,No.6 (1986), pp.1369-1381

(5) Woollacott,M.H.,Shumway-Cook,A.,Nashner,L.M., Aging and posture control: Changes in sensory organization and muscular coordination, International Journal of Aging and Human Development, Vol.23 (1986), pp.97-114

(6) Ishida,M., Tsushima,E.,Miura,T., Muscle activation patterns of lower extremities while standing in response to shoulder or hip perturbation from behind, Annual Report of The Tohoku Section of Japanese Physical Therapy Association, No.12 (2000), pp.35-40

(7) Ishida,M., Tsushima,E., The Order of Muscle Activation at Lower Extremities While Standing in Response to Perturbation from Behind Applied to Different Part of Body and Applied by Different Strength, Journal of 
The Japanese Physical Therapy Association, Vol.28,No.5 (2001), pp.220-224

(8) Kimura,H., Yifa,J., A PID Model of Human Balance Keeping, IEEE Control System Magazine, Vol.26,No.6 (2006), pp.18-23

(9) Ishida,A.,Hozumi,J.,Imai,S.,Ryumae,S.,Shimizu,M., Measurement of visco-elastic properties of muscles around the ankle during standing, Frontiers of Medical and Biological Engineering, Vol.7,No.1 (1995), pp.35-43

(10) Sato,H.,Fujita,K., Role Distribution between Ankle Joint Stiffness and Stretch Reflex in Human Postural Controll, Transactions of the Society of Instrument and Control Engineers, Vol.35,No.5 (1999), pp.600-605

(11) Stephen,N.R.,Britta,H.,Andrew,L.,Jeffrey,C., Effect of Strength and Speed of Torque Development on Balance Recovery With the Ankle Strategy, Journal of Neurophysiology, Vol.88,No.2 (2002), pp.613-620

(12) Savitzky,A., Golay, M.J.E., Smoothing and Differentiation of Data by Simplified Least Squares Procedures, Analytical Chemistry, Vol.38,No.8 (1964), pp.1627-1639

(13) Ae,M., Tang,H., Yokoi,T., ESTIMATION OF INERTIA PROPERTIES OF THE BODY SEGMENTS IN
JAPANESE ATHLETES, Biomechanisms, Vol.11 (1992), pp. 23-33

(14) Yokoi,T., Body Segment Inertia Parameters for Linksegment Model(in Japanese), Journal of the Society of Biomechanisms, Vol.17,No.4 (1993), pp.241-249

(15) Yokoi,T.,Ohyama,K.,Okada,H., Effects of Body Segment Inertia Parameters on the Kinematic and Kinetic Analysis of Human Movement, Japanese Journal of SPORTS SCIENCES, Vol.14,No.5 (1995), pp.545-553

(16) Ae,M., Body Segment Inertia Parameters for Connection between Kinematics and Kinetics - Comparison of Measuring Methods and of Parameters- (in Japanese) Japanese journal of biomechanics in sports \& exercise, Vol.1,No.l (1997), pp.51-62

(17) Uchiyama, Y., Balance and Posture, Activity (in Japanese), The Japanese journal of physical therapy, Vol.36,No.4 (2002), pp.223-232

(18) Sagawa,K.,Abo,S.,Tsukamoto,T.,Kondo,I., Measurement of Forearm Trajectory During Pitching Motion Using Elbow-mounted Senseor, Transactions of the Japan Society of Mechanical Engineers, Series C, Vol.74,No.738 (2007), pp.400-408 